\title{
THE ANALYSIS OF INDICES OF CEREBRAL BLOOD CIRCULATION IN WOMEN-SMOKERS
}

\author{
Lyudmila Aponchuk \\ Department of Human and Animal Physiology \\ Lesya Ukrainka Eastern European National University \\ 13 Svobody ave., Lutsk, Ukraine, 43025 \\ aponchykl@yandex.ru \\ Tatiana Shevchuk \\ Department of Human and Animal Physiology \\ Lesya Ukrainka Eastern European National University \\ 9 Potapova str., Lutsk, Ukraine, 43025 \\ tetyana_shevchuk_2013@ukr.net
}

\begin{abstract}
The results of rheoencephalography of female smokers 17-21 years old and control group were studied and analyzed. The aim of this work was to explain and analyze physiological features of smoking effect on functional changes of regional hemodynamics in smoking women.

The study of cerebral hemodynamics was carried out by the method of rheoencephalography (REG) - automated system of complex examination "Askold", intended for automation of medical tasks processing with input of information in "online" regime (insertion of data directly from examined person). The recording of rheogram was carried out in front-mastoid branches that allowed register REG separately in both hemispheres of brain and determine the main amplitude-temporal characteristics of cerebral blood circulation and changes of vascular tone.

Analyzing the main indices of regional hemodynamics in female smokers, the statistically lower values of time of rheowave delay ( $\mathrm{Ra}$ ) were noted. There was also revealed a decrease of volumetric cerebral blood circulation and increase of resistant arteries tone. There were fixed the moderate asymmetry (from 15 to $25 \%$ ) of blood filling in vertebral-basilar vascular basin (basin of spinal and internal carotid arteries) and the signs of complicated venous outflow in both hemispheres.

Such changes of indices indicate the decrease of volumetric blood circulation of cerebral hemodynamics, striking volume of blood and increase of tone of distribution arteries that testify to the decrease of blood circulation in main vessels, and also smoking is a cause of hypoxia (oxygen deprivation) of cerebral cells as a result of decrease of blood inflow. In the women of control group all indices are within norm that testifies to the normal course of physiological processes in organism.
\end{abstract}

Keywords: smoking, women-smokers, brain, vascular tone, blood circulation, rheoencephalography.

\section{Introduction}

The one of most important problem of the modern society is the increase of people with different types of addictions, and the most spread of them is smoking. The smoking and its medical-demographic and economic results are the subject of scientific interests of many native and foreign scientists [1-3]. Last time in Ukraine under conditions of social-demographic crisis the question of health protection of young generation, especially the one of student age, became urgent [4].

In most countries of the world the phenomenon of smoking and also the prevalence of diseases and deaths, caused by tobacco consumption are considered as an important medical, social and economic problem [5]. For today Ukraine belongs to the countries with high prevalence of smoking not only among men, but also women. Today near $20 \%$ of women of working age smoke in our country [6].

The little doses of nicotine intensify the excitability of cerebral cortex for a short time, then oppress and exhaust the nerve cells that condition the imaginary increase of working capacity of smokers. Brain becomes inured to the nicotine "doping" and begins to request it, and in the case of lack the anxiety and irritability appear. The balance between excitation and inhibition is broken as a result of overexcitation of nerve cells that decreases the intellectual working capacity of brain, because of being exhausted [7]. 
The problem of cerebral vascular injuries is the one of urgent problems of health protection. Its medical and socio-economic importance is conditioned by significant specific weight of cerebral vascular pathology in the structure of morbidity and mortality of population, high indices of temporary disability and invalidism. The studies that demonstrate the interconnection between smoking and cerebral blood circulation are almost absent in modern literature, that is why this problem is urgent for today.

\section{Aim of research}

The aim of this work was to explain and analyze physiological features of smoking effect on functional changes of regional hemodynamics in smoking women.

\section{Materials and methods}

The research was carried out in laboratory of "Ecological physiology" of the department of human and animal physiology of biological faculty of Eastern European University, named after Lesya Ukrainka. The study of cerebral hemodynamics was carried out by the method of rheoencephalography (REG) [8] on the complex of program and automatic methods of medical examination of children and adults "Askold".

The recording of rheogram was carried out in front-mastoid branches that allowed register REG separately in both hemispheres of brain and determine the main amplitude-temporal characteristics of cerebral blood circulation and changes of vascular tone.

The examined contingent included female persons, 17-21 years old. They were divided in 2 groups (according to Fagerstrom test) [9]:

I group - women with smoking experience more than 3 years, who smoke more than 10 cigarettes a day and have the high level of addiction (30 persons);

II group - no-smoking women (30 persons).

To characterize the functional possibilities of cerebral blood circulation there were used the indications of rheoencephalography that characterize the value of pulse blood filling in vertebral basilar basin (basin of spinal and internal carotid arteries) of the right and left hemispheres, the condition of vascular wall (tone, elasticity), relative speed of blood circulation and also the ratio of arterial inflow and venous outflow.

The following indices of cerebral blood circulation were studied in examined persons: the period of pulse fluctuation $(\mathrm{T})$, time of fast filling (ab), time of maximal filling (ax), time of rheowave delay (Ra), amplitude of fast filling (Ab), rheographic index (Ax), dicrotic index (A1), speed of fast filling (Vmax), mean speed of filling (Vmean), coefficient of asymmetry (CA).

For the analysis of results there were used conventional methods of parametric (for processing of quantitative values - Student t-criterion) and non-parametric (for processing of qualitative values - Wilcoxon W-criterion) statistics (depending on the character of values distribution). The statistical processing of data was carried out using MedStat software [10].

\section{Results of research}

The indices of two groups of examined were contrasted for comparative analysis. The analysis of rheoencephalorgaphy results demonstrated that the deviations of such indices from the norm were often observed in examined women (Table 1).

On the Table 1 it can be seen, that the index of time of fast filling (ab) in women of both groups was lower than norm $(0,111-0,121 \mathrm{~s})$ almost by $50 \%(\mathrm{p}>0,05)$. It testifies to the decrease of elastic features of vessels and their resilience.

The index of time of rheowave delay $(\mathrm{Ra})$ in female smokers is reliably lower $(\mathrm{p}<0,05)$, than in the control examined group and is 0,145 s (right hemisphere) and 0,144 s (left hemisphere) (Table 1, Fig. 1). The decrease of this interval is a sign of increase of tone of sclerosis of the main vessels.

In female smokers is observed the decrease of the index of time of maximal filling (ax) in the left hemisphere of brain from the norm 0,111-0,127 s (Table 1), that indicates the difference in tone and elasticity of arteries and big vessels and also their resilience but the reliable difference was not revealed in any group $(\mathrm{p}>0,05)$. 


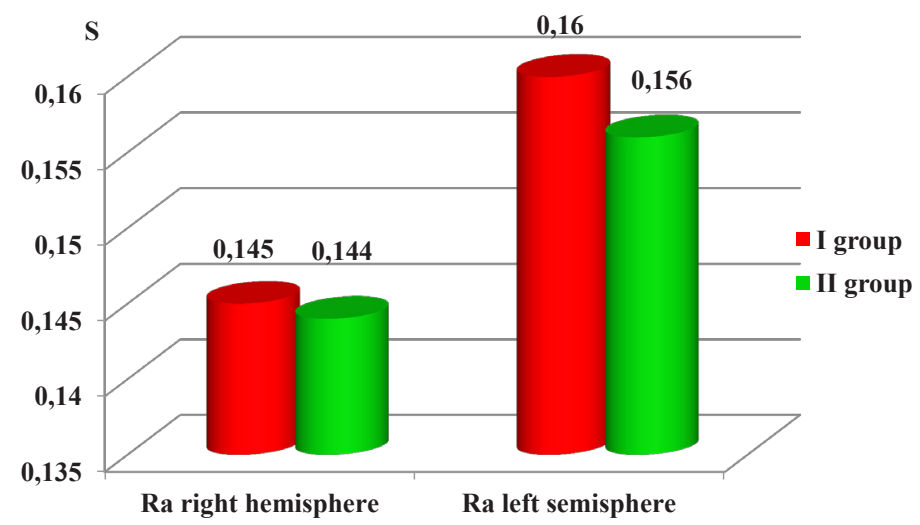

Fig. 1. The time of rheowave delay $(\mathrm{Ra})$ in studied women

The amplitude of fast filling $(\mathrm{Ab})$ in all examined women from both groups was decreased, but the reliable difference was not fixed $(p>0,05)$. In women-smokers this index for right hemisphere was $0,051 \mathrm{Ohm}$, and in women of control group - 0,064 Ohm. The analogous tendency was traced for the left hemisphere (Table 2). The decrease of Ab index almost by $50 \%$ was revealed in all examined women of both groups at the norm 0,124-0,148 Ohm, although in women-smokers, the decrease of this index is more expressed than in the control group ( $p>0,05)$ (Table 2).

Table 1

The parameters of rheoencephalogram of frontal mastoid branches in examined persons, $(n=60)$

\begin{tabular}{|c|c|c|c|c|c|c|}
\hline \multirow{2}{*}{ Index } & \multirow{2}{*}{ Hemisphere } & \multicolumn{2}{|c|}{ Group I } & \multicolumn{2}{|c|}{ Group II } & \multirow{2}{*}{$\begin{array}{l}\text { Reliability of difference } \\
\text { between groups }\end{array}$} \\
\hline & & Median & Error & Median & Error & \\
\hline \multirow{2}{*}{$\mathrm{Ra}, \mathrm{s}$} & right & 0,145 & 0,004483 & 0,160 & 0,01378 & $\mathrm{P}<0,05$ \\
\hline & left & 0,144 & 0,004125 & 0,156 & 0,01681 & $\mathrm{P}<0,05$ \\
\hline \multirow{2}{*}{$a b, s$} & right & 0,052 & 0,04129 & 0,048 & 0,01925 & $\mathrm{P}>0,05$ \\
\hline & left & 0,052 & 0,1881 & 0,052 & 0,002255 & $\mathrm{P}>0,05$ \\
\hline \multirow{2}{*}{$\mathrm{ax}, \mathrm{s}$} & right & 0,128 & 0,1866 & 0,128 & 0,02129 & $\mathrm{P}>0,05$ \\
\hline & left & 0,126 & 0,186 & 0,128 & 0,01571 & $\mathrm{P}>0,05$ \\
\hline \multirow{2}{*}{$\mathrm{Ax}, \mathrm{Ohm}$} & right & 0,081 & 0,033 & 0,0865 & 0,012 & $\mathrm{P}>0,05$ \\
\hline & left & 0,088 & 0,011 & 0,089 & 0,010 & $\mathrm{P}>0,05$ \\
\hline \multirow{2}{*}{$\mathrm{A} 1, \%$} & right & 91,425 & 2,511 & 93,925 & 4,087 & $\mathrm{P}>0,05$ \\
\hline & left & 90,62 & 2,675 & 93,495 & 4,451 & $\mathrm{P}>0,05$ \\
\hline \multirow{2}{*}{$\mathrm{V}_{\max }, \mathrm{Ohm} / \mathrm{s}$} & right & 7,045 & 2,747 & 8 & 0,9264 & $\mathrm{p}>0,05$ \\
\hline & left & 7,6675 & 0,5719 & 7,923 & 0,7911 & $\mathrm{p}>0,05$ \\
\hline \multirow{2}{*}{$\mathrm{V}_{\text {mean }}, \mathrm{Ohm} / \mathrm{s}$} & right & 3,3055 & 0,4392 & 4,66 & 0,7051 & $\mathrm{p}>0,05$ \\
\hline & left & 3,15 & 0,8662 & 4,1735 & 0,7851 & $\mathrm{p}>0,05$ \\
\hline \multicolumn{2}{|c|}{$\mathrm{CA}$} & 17,81 & 4,614 & 26,535 & 11,79 & $\mathrm{P}>0,05$ \\
\hline \multicolumn{2}{|c|}{$\begin{array}{l}\text { Reliability of difference } \\
\text { between hemispheres }\end{array}$} & \multicolumn{2}{|c|}{$\mathrm{P}>0,05$} & \multicolumn{2}{|c|}{$\mathrm{P}>0,05$} & \\
\hline
\end{tabular}

Note: $<0,05$ - data are reliably different 
Table 2

The index of amplitude of fast filling $(\mathrm{Ab}, \mathrm{Ohm})$ in studied persons, $(\mathrm{n}=60)$

\begin{tabular}{|c|c|c|c|c|c|c|}
\hline \multirow{2}{*}{ Index } & \multirow{2}{*}{ Hemisphere } & \multicolumn{2}{|c|}{ Group I } & \multicolumn{2}{|c|}{ Group II } & \multirow{2}{*}{$\begin{array}{l}\text { Reliability of difference } \\
\text { between groups }\end{array}$} \\
\hline & & Mean & Error & Mean & Error & \\
\hline \multirow{2}{*}{$\mathrm{Ab}$} & right & 0,051 & 0,006 & 0,064 & 0,007 & $\mathrm{P}>0,05$ \\
\hline & left & 0,054 & 0,004 & 0,056 & 0,006 & $\mathrm{P}>0,05$ \\
\hline $\begin{array}{r}\text { Relia } \\
\text { bety }\end{array}$ & $\begin{array}{l}\text { f difference } \\
\text { emispheres }\end{array}$ & \multicolumn{2}{|c|}{$\mathrm{P}>0,05$} & \multicolumn{2}{|c|}{$\mathrm{P}>0,05$} & \\
\hline
\end{tabular}

The decrease of the index of amplitude of fast filling testifies to the disorder of blood filling of cerebral vessels and is also a cause of hypoxia (oxygen deprivation) of cerebral cells as a result of decrease of amount of oxygen that is inhaled and increase of blood satiation with carbonic acid gas.

In two groups was not revealed the reliable difference $(p>0,05)$ between the values of rheographic index $(\mathrm{Ax})$ - an important parameter that gives a possibility to determine the relative value of pulse blood filling of intracranial vessels. Rheographic index is decreased in both groups of examined women comparing with norm $(0,129-0,145 \mathrm{Ohm})$ at $\mathrm{p}>0,05$. The Table 1 distinctly indicates that the rheographic index less than 1 testifies to the decrease of blood supply of brain and decrease of volume of circulating blood (hypovolemia).

The rheographic parameter that reflects the tone state of mainly small and middle arteries is dicrotic index (A1), that is on average $50 \%$. It partially depends on peripheral vascular resistance and shows the tendency to increase in all examined persons. The increase of dicrotic index (A1) more than $70 \%$ characterizes the increase of peripheral vascular resistance or hyper-resistivity of the vessels of microcirculatory channel, that can be observed in both groups of examined women at $\mathrm{p}>0,05$ (Table 1).

In women-smokers the speed of fast filling $\left(\mathrm{V}_{\max }\right)$ and mean speed of filling $\left(\mathrm{V}_{\text {mean }}\right)$ show the tendency to increase and are by $1 \mathrm{Ohm} / \mathrm{s}$ lower than in women of control group at $\mathrm{p}>0,05$ (Table 1). It testifies to insufficient filling of small, middle and big arteries and decrease of vascular tone.

The data of rheoencephalogram gave a possibility to reveal the signs of complicated venous outflow (VO) from both hemispheres of brain not only in women-smokers but also in control group of examined women. In women-smokers was observed the complicated venous outflow from both sides $-75 \%$, for control $-52 \%$. In insignificant number of persons the venous outflow was complicated only at the right $(6 \%$ right hemisphere in women-smokers and the same number in the control group) or at the left (6\% right hemisphere in women-smokers and $13 \%$ in the control group). The norm was registered in women of control group - $29 \%$, and for women-smokers only $13 \%$.

The decrease of tone of mean vessels was registered in left hemisphere of brain $30 \%$ in women-smokers and $25 \%$ in the control group of studied persons, at the right -20 and $15 \%$ of examined persons, respectively. In more than half of women from both groups the tone of middle vessels was increased in right and left hemisphere.

In most examined persons from both groups (women-smokers and control) the tone of small cerebral vessels was increased. It was normal only in insignificant number of examined persons.

The one of most informative and physiologically grounded indices of rheogram is a coefficient of asymmetry (CA) that reflects asymmetry of pulse blood filling of intracerebral vessels for right and left hemispheres. Our data demonstrated the moderate and essential asymmetry of blood filling within the studied basin, which values fluctuated within 15-25\% (women-smokers) and $26 \%$ and more (control group) (Table 1).

The type of blood filling asymmetry is defined according to aforesaid parameters. Thus, we observed that in women-smokers S-asymmetry was traced in $24 \%$, and in control - $30 \%$. D-asymmetry was inherent to $50 \%$ of women-smokers and $27 \%$ of control group of examined persons. The absence of asymmetry of blood filling of cerebral vessels in women-smokers was diagnosed in $26 \%$, and in control group by $17 \%$ more often (43\%). 
According to the data of rheoencephalography, in $90 \%$ of women-smokers and control group of examined persons the volumetric blood flow was decreased that is conditioned, most probably, by the presence of atherosclerotic changes of arteries of brachiocephalic zone.

The decrease of striking volume of blood is observed in almost all women of both examined group, it is increased only in 10-15\%. The norm is registered in women-smokers at the left and right only in $3 \%$, the same tendency in control group.

The peripheral resistance (PR) is significantly increased in women-smokers in both hemispheres of brain $94 \%$, and in the control group - $75 \%$. In $4 \%$ of smoking women and in $20 \%$ of control group PR is within norm. Separately in the right hemisphere was registered insignificant increase in women-smokers only in $1 \%$, in control group - 5\%. In $1 \%$ of observed women-smokers PR is increased in the left hemisphere, and it was not registered in the control group.

\section{Discussion of the results of research}

At the study of cerebral blood circulation we established the reliably lower values of time of rheowave delay ( $\mathrm{Ra}$ ) in the group of women-smokers (1 group) in both hemispheres of brain as opposite to the women from control group at $\mathrm{p}<0,05$.

As to the other parameters such as ab and Ax, they are also decreased in women-smokers within physiological norm ( $\mathrm{ab}-0,111-0,127 \mathrm{~s} ., \mathrm{Ax}-0,129-0,145 \mathrm{Ohm}$ ), but the reliable difference between groups was not revealed $(p>0,05)$. The decrease of norm indicates the difference in tone and elasticity of arteries and big vessels and also their resilience.

In the process of research was observed the tendency to increase of $\mathrm{V}_{\text {mean }}$ and $\mathrm{V}_{\text {max }}$. Just this fact explains the abrupt fall of pressure in vessels at acute intoxication by nicotine that leads to vertigo, loss of consciousness and other negative results. In 2-3 min. after inhalation of smoke, nicotine already penetrates within cerebral cells and raises their activity for some time together with short-term widening of cerebral vessels and reflex effect of ammonia on nerve endings of respiratory tract that is subjectively perceived by the smoker as refreshing inflow of forces with smoothing action. But in short time the filling of energy inflow and excitation disappear - it is physiologically connected with coming narrowing of cerebral vessels and decrease of brain activity [11].

Computer interpretation of rheoencephalography data gave a possibility to reveal the signs of complicated venous outflow (VO) $[12,13]$ from both hemispheres of brain not only in women-smokers but also in control examined group.

Depending on the value of asymmetry coefficient several degrees of blood filling asymmetry are distinguished: if coefficient is $7 \%$ and less, there is no essential difference of blood filling, at the value of asymmetry coefficient from 8 to $14 \%$ the blood filling asymmetry is characterized as little. If the asymmetry coefficient is from 15 to $25 \%$, it testifies to the presence of moderate blood filling asymmetry, at coefficient $26 \%$ and more, it is recognized as significant $[14,15]$. Our data showed the moderate (I group) and significant (II group) asymmetry of blood filling within the studied basin.

There were observed changes that testify to the decrease of volumetric pulse blood filling, increase of tone of distribution arteries that is hypertone. That is why it must be noted, that smoking has negative influence on cerebral blood circulation that in further can result in pathologies.

REG data of previous studies $[12,13,16-18]$ also revealed the elastic-tonic changes of vessels and presence of signs of complicated venous outflow in smokers.

There is no sufficient information as to reaction of different systems of organism. It is reported about the increase of tone of sympathetic section of VNS that is manifested in growth of frequency of heartbeat (FHB) and arterial pressure (AP) [19, 20].

Thus, we have studied the state of cerebral blood circulation in women at smoking. In further it would be expedient to study more contingent of examined persons and to divide them in several groups by term and number of smoked cigarettes to improve the results. The insufficient sample of examined persons can influence the reliability of results. At the same time the prospect of our research is the study of influence of smoking on central and peripheral hemodynamics that gives a possibility to make deeper analysis of functional state of cardiovascular system just in women-smokers. 


\section{Conclusions}

1. The results of rheoencephalograpgy revealed that women-smokers are characterized with statistically lower values of time of rheowave delay $(\mathrm{Ra})$ at $\mathrm{p}<0,05$. The other parameters such as $\mathrm{ab}$ and $\mathrm{Ax}$ are also decreased in women-smokers within physiological norm, but the reliable difference was not revealed $(\mathrm{p}>0,05)$.

2. Such change of indices indicates the decrease of volumetric cerebral blood circulation, striking volume of blood, increase of tone of resistance arteries and distribution arteries. The elastic-tonic changes of vessels, manifested in insufficient filling of small, middle and big arteries, increase of peripheral vascular resistance and the signs of complicated venous outflow in smokers that is a cause hypoxia (oxygen deprivation) of cerebral cells as a result of decrease of blood inflow are present.

3. Most indices of the women from control group are within norm that can testify to the normal cerebral blood circulation in examined persons from II group.

\section{References}

[1] Ahulova, O. O. (2012). Osobystisni osoblyvosti molodykh zhinok iz nikotynovoiu zalezhnistiu [Personality characteristics of young women with nicotine dependence]. Visnyk Kharkivskoho natsionalnoho pedahohichnoho universytetu imeni H. Skovorody. Psykholohiia, 44 (1), 12-19.

[2] Ng, M., Freeman, M. K., Fleming, T. D., Robinson, M., Dwyer-Lindgren, L., Thomson, B. et. al. (2014). Smoking Prevalence and Cigarette Consumption in 187 Countries, 1980-2012. JAMA, 311 (2), 183. doi: 10.1001/jama.2013.284692

[3] Pirie, K., Peto, R., Reeves, G. K., Green, J., Beral, V. (2013). The 21st century hazards of smoking and benefits of stopping: a prospective study of one million women in the UK. The Lancet, 381 (9861), 133-141. doi: 10.1016/s0140-6736(12)61720-6

[4] Belova, N. I., Burtsev, S. P., Vorobtsova, E. A., Martynenko, A. V. (2006). Otnoshenie studentov k zdorovyu i zdorovomu obrazu zhizni [The ratio of students to health and a healthy lifestyle]. Problemy sotsialnoy gigieny, zdravoohraneniya i istorii meditsiny, 1, 14-15.

[5] Preventing Tobacco Use among Youth and Young Adults (2012). US Departament of Health and Human Services. Executive Summary, 11.

[6] Kvasha, O. O., Gorbas, I. M., Smirnova, I. P. (2010). Mediko-sotsíal’niy proyekt «Zdorov’ye bez kureniya». Rekomendatsiyi z profilaktyky i likuvannya tyutyunopalinnya [Medical sotsialny Project «Health without smoking». Recommendations for prevention and treatment of tobacco]. Zdorov'ya Ukrayiny, 2 (231), 34-36.

[7] Chagayda, M. O. (2013). Vpliv palinnya na organizm lyudini [The impact of smoking on the human body]. Vseukrayinskiy naukovo-populyarniy zhurnal. Bezpeka zhittediyalnosti, 4, 5.

[8] Revenko, S. V. (2012). Garmonicheskie perspektivy reografi [Harmonic prospects rheographs]. Nervno-myshechnye bolezni, 4, 8-18.

[9] Smirnova, I. P., Kvasha, O. O., Gorbas, I. M., Davidenko, N. V. (2006). Rekomendatsiyi z profilaktyky i likuvannya tyutyunopalinnya [Recommendations for prevention and treatment of tobacco]. Kyiv, 16.

[10] Lyah, Yu. E., Guryanov, V. G. (2012). Matematicheskoe modelirovanie pri reshenii zadach klasifikatsii v biomeditsine [Mathematical modeling in solving the classification problems in biomedicine]. Ukrains'kiy zhurnal telemeditsini ta medichnoi telematiki, 10 (2), 69-76.

[11] Malko, M. M., Romanenko, K. V. (2012). Osoblyvosti elektrokardiohrafichnykh pokaznykiv pry dykhal'nyy funktsional'nykh probakh [Features electrocardiographic indicators in respiratory function tests]. Aktualni pitannya biologiyi, ekologiyi i himiyi, 1, 46-50.

[12] Vlasova, O. V., Popova, G. A., Kovalnogov, A. V. et. al. (2008). Izmeneniya tsentralnoy gemodinamiki i mozgovogo krovotoka pri kurenii u studentov [The changes of central hemodynamics and cerebral blood flow during smoking in students]. Vestnik NGU. Seriya: Biologiya, klinicheskaya meditsina, $6(3), 48-55$. 
[13] Vlasova, O. V., Popova, G. A., Tsirkin, V. I. (2008). Pokazateli tsentral'noy gemodinamiki i mozgovogo krovotoka $\mathrm{u}$ zhenshchin pri kurenii [Central hemodynamics and cerebral blood flow in women with smoking]. Voprosy narkologii, 5, 77-86.

[14] Kuznetsov, A. A., Permyakov, S. A. (2012). O estestvennoy normalizatsii diagrammy ritma serdtsa [About the natural normalization of heart rate chart]. Trudy Nizhegorodskogo gosudarstvennogo tehnicheskogo universiteta im. R. E. Alekseeva, 4 (97), 363-368.

[15] Slobodinskiy, A. P., Vasilkivskiy, I. V., Petruk, V. G., Kvaternyuk, S. M. (2014). Vpliv promislovih aerozoliv na dinamiku pnevmokoniozu v Ukrayini [The impact on the dynamics of industrial aerosols pneumoconiosis in Ukraine]. Nauka. Molod. Ekologiya, 194-198.

[16] Korovina, L. D., Zaporozhets, T. M. (2015). Zv’yazki krovopostachannya golovnogo mozku studentiv zi stanom vegetativnoyi nervovoyi sistemi ta faktorami riziku [Links brain blood supply students with the state of the autonomic nervous system and the risk factors]. Vìsn. Dnìpropetr. Unìv. Ser. Biol. Med., 6 (1), 68-73.

[17] Perminov, A. A., Kuvshinov, D. Yu., Rybnikova, O. S. (2008). Gendernye osobennosti vliyaniya kureniya na vegetativnuyu nervnuyu sistemu u lits yunosheskogo vozrasta [Gender-specific effects of smoking on the autonomic nervous system in young people]. Sibirskiy meditsinskiy zhurnal, 3-2, 64-69.

[18] Syvolap, V. V., Poznanskaya, E. A., Nikulina, R. P., Vizir, A. V. (2014). Osobennosti intra-i ekstrakranialnogo krovotoka u bolnyh gipertonicheskoy boleznyu II stadii v zavisimosti ot statusa kurilshchika [Features of intra and extracranial blood flow in patients with essential hypertension stage II, depending on the smoker status]. Patologiya, 1 (30), 25-29.

[19] Arosio, E., De Marchi, S., Rigoni, A., Prior, M., Lechi, A. (2006). Effects of smoking on cardiopulmonary baroreceptor activation and peripheral vascular resistance. European Journal of Clinical Investigation, 36 (5), 320-325. doi: 10.1111/j.1365-2362.2006.01628.x

[20] Karakaya, O., Barutcu, I., Kaya, D., Esen, A. M., Saglam, M., Melek, M. et. al. (2007). Acute Effect of Cigarette Smoking on Heart Rate Variability. Angiology, 58 (5), 620-624. doi: 10.1177/0003319706294555 